\title{
Tasawwuf and Its Role in Minimizing Corruption and Insurgency Among Muslims in Northern Nigeria
}

\author{
Aishatu Abubakar Kumoa, Fatima Abubakarb
}

\begin{abstract}
Tasawwuf which refers to as zuhd during the time of the prophet is being distorted with new concept contrary to the teachings of the prophet and his companions. As a result, it is misunderstood by some Muslims and few bothers to look into its reality. The current practiced of tasawwuf to some extend contradictory to the zuhd displayed during the time of the prophet and his companions. The adulteration in it has made many Muslims not to pay attention: less learning or benefitting from its fruits. The current corrupt situation among Muslims in Northern Nigeria can be attributed to absence of zuhd. The fact that corrupt mind can lead to many problems, generated into insurgency: causing a lot of damages and loss of life and property. Therefore, the implementation of zuhd according to the teachings and practice of the prophet, his companions, and early Sunni scholars can be of assistance in reducing the level of corruption among Muslims in Northern Nigeria. This can be achieved through proper Islamic education mainly for the attainment of Allah's pleasure. By this, a Muslim seeks for the worldly gains as a means to an end, and deceased from following his whims and caprices.
\end{abstract}

\section{Keywords}

Zuhd, Muslims, Northern Nigeria, corruption, insurgency

Northern Nigeria is known to be Islamic oriented with Qadiriyya and the Tijaniyyah as the adopted and cherish Sufi order. The secular state of the country makes it very difficult to abide by the Islamic teachings. The heretic Sufi doctrines and distortion of the actual asceticism taught by the prophet and his companions did not allow the Muslims to adopt the real Sufism or Zuhd in Islam. These brought about some distortions in moral behavior that led to corruption and insurgency which have left millions of people in the region feeling frustrated and desperate for change. Corruption flourished in Nigeria chiefly because no government credibly and honestly committed itself to fighting it. As such, it manifested as a culture in the society. The in-depth of corruption has led to insurgency mostly among youth that are used by the politicians and others for their personal interest. This has brought about loss of lives and properties and mostly affecting Muslims in the region.

\footnotetext{
anternational Islamic University, Malaysia bGombe State University, Nigeria

\section{Correspondent Author:}

Aishatu Abubakar Kumo, Department of Religious Studies, Faculty of Arts and Social Sciences, Gombe State University, Nigeria

E-mail: Jauroji1988@gmail.com
} 


\section{DEFINITION OF THE TERM “CORRUPTION"}

The world corruption etymologically, is derived from the verb corrupt, which is also derived from the Latin word corruptus, which means "to change from good to bad in moral, manner or action" or "to degrade with unsound principles or moral values" (Webster 1976). Corruption is also the misused of entrusted power (by heritage, education, marriage, election, appointment, or whatever else) for private gain ${ }^{1}$.

In the Qur'an and Sunnah, corruption refers to a broad range of behavioral digressions that threaten the social, economic, and ecological balance. Such acts are clarified at various places in the Qur'an in plain language, in terms of being just or unjust, with reference to their detrimental impact on social organization, and within relation to the standards of moral virtue.

From the Islamic point of view corruption (Fasad) literally, encompasses mischief, abuse, rottenness, spoiled-ness, decay, decomposition, putrefaction, depravity, wickedness, viciousness, iniquity, dishonesty, and perverted-ness (Wehr 1976). Corruption covers a wider sphere in Islam which includes bribery, misappropriation, and embezzlement of public funds. That is to say, any behavior that contradicts the teachings of the Qur'an and the Sunnah of the Prophet [(SAW-Sallalahu Alaihi Wa sallam) Peace be upon him] is considered as a corrupt practice. The Qur'an uses various terms and concepts to refer to corrupt practices. Some of these terms include Fasad (mischief), Fisq (impiety), Zulm (wrong-doing), and so on.

\section{TYPES OF CORRUPTION}

As the word "corruption" means the state of being bad and dishonest, especially in matters concerning money. It creates a negative impact to the country's education, occupation, living style, and mostly the humanity.
Corruption became a sway all over the world nowadays. It can be categorized in three types. The first is political corruption includes kidnapping, murder, violence, injustice, etc. To win in election, political leaders are using wine, women, wealth, and everything among the people. The next is administrative corruption that comprises of persons like the higher authorities, officers, police officers, clerks, peons, etc. For example, give money, and get anything difficult, easily, spend money no need to visit the office, you will get driving licenses. By bribe, a blind and handicap can also get driving license. Money makes the mare go. In hospital, court, and other government offices, money works for any kind of job. Lastly, professional corruption that related to business which includes duplicating medicines, import items/theft items, hygienic products, mixture in eatables, etc. Mixture in spices, stones in cereals, animal fats in ghee, kerosene in petrol, etc., are under professional corruption. All these corruptions are due to both the leaders, as well as the citizens. The leaders are promoting the citizen toward corruption by showing money. The contributing factor to corruption is modernization of life style like eat, drink, be merry. The modern society of Nigeria does not think about the country and its future ${ }^{2}$.

\section{CAUSES OF CORRUPTION AMONG MUSLIMS IN NORTHERN NIGERIA}

People do not indulge in corrupt practice because they like doing so; rather, it is often their only option. To some extent, the causes of corruption vary from place to place. Nowadays, Muslim communities in Northern Nigeria are seriously afflicted with the disease of corruption due to the injustices of their leaders in managing the affairs of Muslim community. Two reasons are attached to the causes of corruption among Muslims in the study area. One of such is the Nigerian environment, and the other is the individual. 


\section{Individual Causes}

Man as an individual is bound to have some lapses being weak by nature. That is why Allah sends messengers to guide people to the right path. The famous and essential aspect of Ibadah is knowledge. Ignorance can lead to disbelieve as well as all kinds of vices. Likewise, misguided and distorted religious knowledge can be worst. Having wrong impression, quoting out of context and deviant teachings are all part of the causes. The first revelation was about seeking for knowledge and is the most important of all matters in Islam. The consciousness of Allah in the daily life of Muslim in Northern Nigeria seems to be very rear as the country is secular and the concept is having a negative impact on the Muslims. The consciousness of Allah is absent in most of the Muslims day to day's activities. Very few Muslims are conscious of the thorny path as they walk through this deceptive world. This makes them to indulge in corrupt practice and abuse the power at their disposal and forget the purpose of their creation.

Once there is no Allah's consciousness, the faith lacks strength to control the heart from following its whims and caprices. This leads to one of the diseases of the heart-greediness and can lead to many spiritual diseases if care is not taken, like selfishness, love of the world, fear of poverty, arrogance, competing for worldly affluent, to mention few. Therefore, the heart of the Muslim in Northern Nigeria becomes weak to overcome the surrounding contributing factors, at the end, falls a victim of disobedience to his creator and sustainer. Thereafter, loose sense of shame and proof to the prophetic saying (An-Nawawi: 9) and thereafter become deaf, dumb, and blind (2: 18) from the signs of Allah and adopt his nafs as lord (25: 43).

\section{Environmental Causes}

Environment plays a vital role in shaping the life of an individual. Besides the secular system operating in
Nigeria, there are other factors contributing to the corrupt behavior of the Muslims in Northern Nigeria. These includes among other things unwillingness to stop corruption. The government lack strong-willed or impartial anti-corruption agencies. Impotence of governments in the face of corruption is mimicked in the private sector. Corrupt business practices continue because executives are often the beneficiaries of those practices. As a result, public institutions in turn exacerbate poverty. The poor engage in corrupt practices out of desperation, unfortunately, those in power are the beneficiaries at the long run. Thus, the most corrupt countries often have the poorest citizens, and when the poor do not have what to eat, are subsequently forced to make money through cut-corners which are corrupt. The difficulty in three square meal leads to poor education. Struggling to survive makes education the least in priorities. As the corrupt government does not pay attention to the education of its citizens. Literacy can prevent corruption in a number of ways especially Islamic education. Basic education makes people more likely to find stable careers, and therefore are less desperate.

Greediness is an important cause of corruption as the people with the most in the Nigerian society are not content with what they have. The more they have, the more they want to acquire. Therefore, politics serves as an avenue for greed as leaders use their positions to embezzle vast amounts of public funds meant for the public good. Then the result end is unemployment. The unemployed are more likely to succumb to illegal ways of making money out of desperation. How do the countries with the highest rates of unemployment fare on the corruption scale (Dike 2015)? Apart from that, money and other resources extracted by the use of coercion, violence or threats to use force, leads to insurgency. This comes from those in authority and an office holder prefers his friends, family, and anybody close and trusted ${ }^{3}$. 


\section{INSURGENCY}

An insurgent is a person who takes part in an armed rebellion against the constituted authority (especially in the hope of improving conditions). He can be a member of an irregular armed force that fights a stronger force by sabotage and harassment and can also be a person who takes part in an armed rebellion against the constituted authority (especially in the hope of improving conditions) ${ }^{4}$. Therefore, insurgency is an act of rebellion against a constituted authority through arms sabotage and destruction with the hope of improving the so-called distorted condition.

\section{Causes of Insurgency Among Muslims in Northern Nigeria}

As a corrupt country caused by the above mentioned reasons, they all may led to insurgency despite the fact that the country has a high level of economic growth in recent years. But the fruits of such growth are restricted to a limited number of people at the same time with increasing rate of unemployment and poverty among the youth in the study area. Indeed, the evidence actually suggests a greater concentration of wealth in fewer hands, at a time of a growing cohort of young people with minimal employment prospects -some 40 million 18-25 year olds are unemployed-resulting in disempowerment, resentment, and anger.

The Research Director of the Nigerian Economic Summit Group (NESG), Dr. Sope Williams Elegbe, who the authors consulted on the poverty statistics, says that:

The increasing poverty in Nigeria is accompanied by increasing unemployment. Unemployment is higher in the north than in the south. Mix this situation with radical Islam, which promises a better life for martyrs, and you can understand the growing violence in the north. Government statistics show that the northern states have the highest proportion of uneducated persons. If you link a lack of education and attendant lack of opportunities to a high male youth population, you can imagine that some areas are actually a breeding ground for terrorism. (Rogers 2012)

Thus, a corrupt country is likely to be a breeding ground for insurgency. They are known to destructively attack churches, mosques, schools, police stations and government, civilian, old, young, men, and women, private and public owned facilities with a kind of guerilla warfare tactics (Taiwo 2014). All these are done claiming to a miss-quoted text and unguided teachings that are contradictory to Islam. The bases of it are poverty and limited understanding of Islamic teachings.

\section{CONCEPT OF ZUHD: ASCETCISM IN SUFISM}

Concept of zuhd (asceticism) has a pivotal place in the way of "tasawwuf". It means lack of desire, staying away from anything vogue and being content with less. A heart with zuhd gives less importance to worldly needs and advantages, refrains from being opportunist and selfish, carries as little as concerns for self-benefits and becomes fully satisfied with whatever is present in any given circumstances. In truth, the scholars have defined Zuhd thusly: To abstain from which will not benefit a person on the Day of Judgment ${ }^{5}$.

Therefore, Zuhd does not mean wearing scruffy clothing, withdrawing from people and keeping away from society, or fasting constantly. The prophet (peace and blessings of Allah be upon him) is the leader of all ascetics, but he wears new clothes; adorns himself to meet delegations, for Jumu'ah, for celebrations, interacts with people exhorts them to do well, teach them about their religion as well as forbade his companions to fast constantly. Rather, zuhd means shunning that which is haram and that which Allah hates; avoiding shows of luxury and overindulging in worldly pleasures; focusing on doing acts of worship; and making the best preparation for the hereafter. The best explanation of that is the life of the prophet. 
Zuhd can thus be described as not having joy for worldly possessions, not regretting for such losses and not having desire for what is not being owned. So, Zuhd does not mean pursuing a clerical life and shutting oneself in a remote monastery and cease working, it means trying to refrain from unnecessary worldly savors and not be over-busy with mundane activities. In other words, it means submission to afterlife, not this world ${ }^{6}$.

\section{ZUHD OF THE COMPANIONS}

Zuhd has played a vital role in shaping the life of the companions of the prophet (SAW) and those that come after them. Mankind have found peace and happiness in religion through moral virtues (Fethullah 1996: 5). As a religion, Islam takes care of both the mundane and the spiritual life of its followers. Even though Islam allows the believer to pray for the good things of this world and the world-to-come, there are quite a number of verses as well as a hadith enjoining the believers to be moderate in their life style, and warning them against deep indulgences in worldly affairs. That explains reason why the Quran has described such good things of this world as treasures and chatters of deception. The Qur'an categorically mentioned: Know ye (all) that the life of this world is but play and amusement, pomp and mutual boasting and multiplying (in rivalry among yourselves, riches and children what is the lift of this world but goods and chattels of deception) (57: 29).

The spiritual essence has been made clear in this verse as well as the purpose of life. Spiritual up-liftment demands that a believer must be satisfied in his obedience to Allah, and should ignore the immediate benefit of the good things of this world. Children and wealth are means for human trial in this world, and certainly a through them to load believers stray. The Qur'an observes that: Many of the attractive vanities of the world are but nets set by the evil one to deceive man. The only thing real and lasting is the good life lived in the light of God (57: 20). The companions comply with the teaching of this verse while the prophet had already, through the guidance of Allah (Muslim: 139), become used to this type of life long before, he was called to the prophetic mission (33: 21). He became a role model for them and stated to be send as such in the Qur'an (Osman 2011: 43). Abu Huraira reported that Allah's Messenger (may peace be upon him) said: When one of you looks at one who stands at a higher level than you in regard to wealth and physical structure, he should also see one who stands at a lower level than you in regard to these things (in which he stands) at a higher level (as compared to him). Allah's Messenger (may peace be upon him) said: The world is a prison-house for a believer and paradise for a non-believer (Muslim: 42: 7058).

\section{THE ROLE OF ZUHD IN CURBING CORRUPTION AND INSURGENCY}

In tackling a problem, the root needs to be diagnosed and treated well. The essential opium to be treated are ignorance, greed, self-reliance, and instilling the spirit of brotherhood among Muslims. The life style of the companions and how the prophet conducted his teachings are worth emulating. He taught the companions knowledge and stated it as compulsory. And they lived by practical examples of his teachings.

\section{The Role of Zuhd in Education}

From the wisdoms in which Islam emphases on seeking for a genuine knowledge is, its absence leads to many vices. All the above mentioned causes are in one way or the other attributed to illiteracy or ill-gotten knowledge. Therefore, scholars have a role to play in guiding Muslims. The inculcation of pure Islamic education on people delivers the whole society from abyss of destructions. The intellectual and spiritual training through the prophetic method of asceticism serves as a channel of attaining moral and 
intellectual maturity and it goes hand in hand (Sulaiman 1986). Thus, acquiring genuine Islamic knowledge and putting it into practice make a person deceased from blind imitation. The companions of the prophet put into practice each verse learned before proceeding to the next. As such searching for knowledge by devoting oneself to moral rectitude and devotion to the performance of obligatory duties and avoidance of prohibited things is the only way of salvation. A person behaves as if in the presence of Allah whether alone or with others. Likewise, the Sunnah should be followed in all ramifications, and manifest a good character and a source of comfort and happiness to others. There is no two ways about it, these can be only be achieved through the actual teachings of the prophet and his companions.

\section{Zuhd in Curbing Greed}

Human existence in life is surrounded by certain necessities. Some are basic and the preservation of life depend on them, while others non-essential and constantly changes which can never be fulfil in total. Naturally, man seeks for money and struggles with all his might against all problems and difficulties that might stands on his way to make more money. As the condition of people varies, a person surrounded by poverty and weakness, stars to seek sustenance by all means possible to eradicate the poverty. At the same time, the rich became afflicted with conceit and arrogance. As a result of the wealth and security he has for himself, he became intoxicant and evils inspiration endlessly battle in his mind (Mujtaba 1990).

A greed person is never satisfied, therefore, living the life like a wayfarer reminds him of his position in this world. Contentment with what a Muslim has and reliance on Allah makes him to overcome some of his shortcomings. The consciousness of Allah he acquires through the Islamic education he has, guides him to attain salvation and be free from greed. Allah is enough for those who relied on him (65: 3). The heart of the zahid is must of the time occupied with the remembrance of Allah. Therefore, worldly desires are of less value to him. So, zuhd here if inculcated from inception with education, can be of paramount importance in preventing greediness.

\section{Zuhd and Self-Reliance}

Asceticism does not mean relaying upon others for a lively hood. The companions despite their being poor people in this material world, they struggle for their livelihood through hard-work without neglecting what was obligatory upon them toward Allah and his messenger. The prophet said: “A person does not eat a meal better than that which he eats from the work of his hand; for the prophet of Allah, Dawud used to eat from the work of his hand" (Al-Bukhari: 2072). He also said: "By him in whose hand is my soul, indeed for one of you to take his rope and gather fire wood is better than asking of anyone, whether he gives him something or refuses to" (Al-Bukhari: 1470). Narrated from Ibn Mas'ud, the prophet said, “Any man who imports something into one of the towns of the Muslims-being patient and anticipative-sells it at the current day's price that's, without waiting for the price to rise-will have the same rank with Allah as the martyrs". Then, he recite the verse of the Qur'an: And others travelling the lands seeking the bounties of Allah, and others fighting for the sake of Allah (73: 20). A pious Muslim will not allow himself to be utilized for others to benefit, he makes the best use of his time and utilize the potentials in him to seek for livelyhood.

\section{Zuhd and Brotherhood}

The Islamic brotherhood is stronger than blood ties. The fundamental teachings of the prophet to his companions about Islamic brotherhood serve as a precedence to others. Love is the foundation of security and comfort. The ties which bring various elements of a society to each other are those built on true Islamic love and brotherhood. It is not based on 
personal interest, but in Allah. As such, able to satisfy human soul with love and comfort (Mujtaba 1990). Hence, the mind should be free from nursing any hatred or enmity toward fellow Muslims, or being unduly anxious over worldly matters. Rather it will be occupied with thought of the hereafter, in order to counter balance the preoccupation with this deceptive world.

The prophet said:

A Muslim is the brother of a Muslim. He neither oppresses him nor humiliates him nor looks down upon him. The piety is here, (and while saying so) he pointed toward his chest thrice. It is a serious evil for a Muslim that he should look down upon his brother Muslim. All things of a Muslim are inviolable for his brother in faith: his blood, his wealth, and his honor. (Sahih Muslim: 6219)

Narrated Abu-Hurairah: Allah's Apostle said: "Verily, Allah would say on the Day of Resurrection: Where are those who have mutual love for My Glory's sake? Today I shall shelter them in My shadow when there is no other shadow but the shadow of Mine” (Sahih Muslim: 6225).

Various narrations from the prophetic hadith has emphases the importance of Muslim brotherhood. He said:

None of you truly believes unless he wishes for his brother what he wishes for himself. Do not envy one another; do not inflate prices one to another; do not hate one another; do not turn away from one another; do not undercut one another, but be you, oh servants of Allah, brothers.

Therefore, abiding by the Sunnah of the prophet saves the Muslims from the present problems of corruption and insurgency that leads to Muslims against a Muslim. It at the end opens a gate for an enemy to attack Muslims unaware.

\section{CONCLUSIONS}

Finally, the earlier practices of the companions of the prophet as taught by him are the path toward salvation in the hereafter as well as comfort and security in this world. Putting into practice the real Zuhd or Sufism now is a solution to so many problems, because it inculcates into the heart consciousness of Allah, abiding by his rules and as much as possible deceased from disobeying him. This world is meant to be sought for the pleasure of Allah, it should not be an end in itself. Therefore, adopting Zuhd in all ramifications helps control must of the problems confronting Muslims in Northern Nigeria.

\section{Notes}

1. Retrieved http://www.corruptie.org/en/corruption.

2. Retrieved http:// www.gnpai.org/researchlibrary/corruption.

3. Retrieved http://www.acl.ng/resource/corruption.

4. Retrieved http://www.audioenglish.org/dictionary/.

5. Retrieved http://www.SalafyInk.com.

6. Retrieved http://www.islamoformation.com/wp-content.

\section{References}

Ahmad, A. M. N.d. Beware of Sufism, and Those Who Call to Sufism Under the Guise of "Zuhd" or Anything Else. Retrieved (http://www. SalafyInk.com).

Ali, Y. 1998. Holy Qur'an Meanings and Commentary. Beirut, Lebanon: Manar intl Publishers.

Dike, V. E. 2005. "Corruption in Nigeria: A New Paradigm for Effective Control.” Africa Economic Analysis 24(8):2011. Retrieved (http://www.acl.ng/resource/corruption_in_ Nigeria_Control.pdf).

Fethullah, G. 1996. Criteria or the Light of the Way 1. London: True star.

Khan, M. M. N.d. The Translation of the Meaning of Sahih Al-Bukhari: Arabic-English. Beirut, Lebanon: Dar Al-Arabia.

Mohiuddin Yahya Ibn Sharaf al-Nawawi. 1977. Forty Hadith. Retrieved (http://www.hadithcollection.com/an-nawawisforty-hadith.html).

Mujtaba, S. M. 1990. Youth and Morals. Translated by A. M. Odeh. Qum; Iran: Islamic Culture Development Office.

Muslim, H. M. 1971. Sahih Muslim. Translated by A. H. Siddiq, Beirut, Lebanon: Dar al-Arabia.

Osman, N. T. 2011. Sufism: A Path Towards the Internalization of Faith (Ihsan). Istanbul, Turkey: Erkam.

Rogers, P. 2012. "Nigeria: The Generic Context of the Boko 
Haram Violence.” Monthly Global Security Briefing. Retrieved (http://www.oxfordresearchgroup.org).

Salisu, M. A. 2000. Corruption in Nigeria. Retrieved (http://www.lums.co.uk/publications).

Sulaiman, I. 1986. A Revolution in History: The Jihad of Usman Dan Fodio. New York; London: Mansell.

Taiwo, A. 2014. The Root Cause of Boko Haram and Other Insurgent Groups in Nigeria, Report on Apr 21, 2014. Retrieved January 26, 2015 (http://saharareporters. com/2014/04/21/root-cause-boko-haram-and-other-insurge nt-groups-nigeria).

Uzochukwu, M. 2015. Corruption: Causes and Solutions. Retrieved January 23, 2015 (http://uzochukwumike. hubpages.com/hub/corruption-solutionandcuses).

Webster, M. 1976. Webster's Third New International
Dictionary and Seven Language Dictionary. Merriam Webster.

Wehr, H. 1976. The Hans Wehr Dictionary of Modern Written Arabic (J. N. Cowan). 3rd ed. Retrieved (http:// www.gnpai.org/researchlibrary/corruption).

\section{Bios}

Aishatu Abubakar Kumo, Ph.D., International Institute of Islamic Thought, International Islamic University, Malaysia; research field: Fiqh and Usul-al-Fiqh.

Fatima Abubakar, Ph.D., Religious Studies Department, Gombe State University, Gombe, Nigeria; research field: Islamic history. 